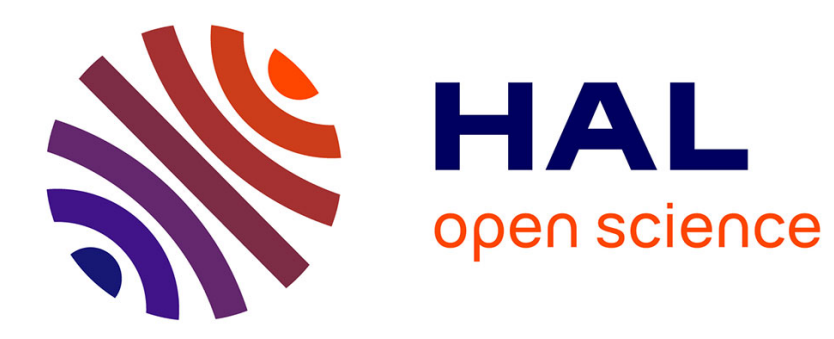

\title{
Parsing protein sulfinic acid switches
}

Sophie Rahuel-Clermont, Michel Toledano

\section{To cite this version:}

Sophie Rahuel-Clermont, Michel Toledano. Parsing protein sulfinic acid switches. Nature Chemical Biology, 2018, 14 (11), pp.991-993. 10.1038/s41589-018-0151-z . hal-02075667

\section{HAL Id: hal-02075667 \\ https://hal.univ-lorraine.fr/hal-02075667}

Submitted on 1 Feb 2022

HAL is a multi-disciplinary open access archive for the deposit and dissemination of scientific research documents, whether they are published or not. The documents may come from teaching and research institutions in France or abroad, or from public or private research centers.
L'archive ouverte pluridisciplinaire HAL, est destinée au dépôt et à la diffusion de documents scientifiques de niveau recherche, publiés ou non, émanant des établissements d'enseignement et de recherche français ou étrangers, des laboratoires publics ou privés. 


\section{PARSING PROTEIN SULFINIC ACID SWITCHES}

Sophie Rahuel-Clermont ${ }^{1}$ and Michel B. Toledano ${ }^{2}$

${ }^{1}$ Université de Lorraine, CNRS, IMoPA, Biopôle, campus Biologie-Santé, F-54000 Nancy, France

${ }^{2}$ Institute for Integrative Biology of the Cell (I2BC), CEA-Saclay, CNRS, Université Paris-Saclay, DBJC/SBIGEM, Oxidative Stress \& Cancer, 91191 Gif-sur-Yvette, France

Correspondence: michel.toledano@cea.fr

\begin{abstract}
The proteome-wide application of a probe that selectively labels cysteine residues oxidized to the sulfinic acid form reveals the mammalian $S$-sulfinylome and uncovers novel substrates of the sulfinyl reductase sulfiredoxin, opening yet unexplored realms of cysteine-based redox regulation.
\end{abstract}

The sulfur atom of the thiol side chain of cysteine (Cys) endows this amino acid with a rich redox chemistry that is exploited in multiple cellular functions. Sulfur chemical reactivity also renders cysteine vulnerable to oxidation to the sulfinic $\left(\mathrm{R}-\mathrm{SO}_{2} \mathrm{H}\right)$ and sulfonic $\left(\mathrm{R}-\mathrm{SO}_{3} \mathrm{H}\right)$ acid forms, which were historically considered to be irreversible oxidative protein damage. The advent of mass spectrometry (MS) allowed the identification of cysteine sulfinic acids in a handful of proteins, in particular the antioxidant peroxiredoxin family (Prx) ${ }^{1}$, and then showed that, unexpectedly, the $\mathrm{R}^{-} \mathrm{SO}_{2} \mathrm{H}$ moiety can be reduced by sulfiredoxin $(\mathrm{Srx})^{2}$. Still, the biological scope of cysteine residue sulfinylation has remained totally unexplored due to a lack of tools for its identification. In a new study, Akter and Fu et al. developed a chemical tool, named DiaAlk, for selectively trapping and tagging sulfinic acids ${ }^{3}$. Combined with click chemistry and quantitative proteomics, DiaAlk made it possible to reveal the native $S$-sulfinylome of human cell lines and, remarkably, to identify new Srx substrates.

Recognition of the extraordinary protein functionality endowed by cysteine residues has followed the slow pace of biochemical and molecular tool development (Fig. 1). For decades, cysteine has been known as a residue that provides conformational stability to proteins by forming covalent disulfide bonds (R-SS-R') or by coordinating metals, or that serves as catalytic center in various classes of enzymes. Thioredoxin and thioredoxin reductase, which reduce disulfide bonds through thiol-disulfide exchange, were discovered as the hydrogen donor system for ribonucleotide reductase (RNR $)^{4}$. Later discoveries included the regulation of protein function by disulfide bond formation in response to $\mathrm{H}_{2} \mathrm{O}_{2}$ (ref. 5), by $S$-nitrosylation (R-SNO) in response to nitric oxide ${ }^{6}$, and the regulated cellular production of $\mathrm{H}_{2} \mathrm{O}_{2}$ by NADPH oxidases (Noxs) during growth factor signaling ${ }^{7}$. These observations, together with the advent of MS, led to the new concept of cysteine-based redox sensing and signaling ${ }^{8}$.

The R-SOH form of the cysteine residue is central in redox sensing and signaling, occurring on multiple proteins in cells stimulated by growth factors, as shown by shotgun redox proteomics. R$\mathrm{SOH}$, which is formed by the reaction of a nucleophilic cysteine residue with $\mathrm{H}_{2} \mathrm{O}_{2}$, or by R-SNO hydrolysis, is intrinsically instable, as it readily forms a disulfide by condensation with a proximal thiolate, a sulfenylamide by reaction with a proximal nitrogen, or a sulfinic $\left(\mathrm{R}-\mathrm{SO}_{2} \mathrm{H}\right)$ and then a sulfonic acid $\left(\mathrm{R}-\mathrm{SO}_{3} \mathrm{H}\right)$ by further oxidation. The cysteine sulfinic acid cannot be reduced by common thiol reductases, and its initial identification in very few enzymes meant it was viewed as an exotic modification until its identification in Prxs. Prxs are antioxidants that reduce $\mathrm{H}_{2} \mathrm{O}_{2}$, thereby forming a catalytic R-SOH, which either condenses into a disulfide reduced by thioredoxin, or is further oxidized to the $\mathrm{R}-\mathrm{SO}_{2} \mathrm{H}$ form when levels of $\mathrm{H}_{2} \mathrm{O}_{2}$ are high, inactivating enzyme antioxidant function ${ }^{1}$. The finding that sulfinylation is a genetically encoded attribute, occurring in eukaryotes but not prokaryotes $^{9}$, and is reversed by enzymatic reduction by $\mathrm{Srx}^{2}$ changed the prevailing view of this modification from an irreversible form of protein damage to an evolutionarily acquired regulatory switch. The $S$-sulfinic acid switch regulates several cellular functions by its effect on cellular $\mathrm{H}_{2} \mathrm{O}_{2}$ levels ${ }^{10}$, and also converts Prxs into a potent protein chaperone during peroxide stress and aging ${ }^{11}$. Whether the $S$-sulfinic acid switch regulates other $\mathrm{H}_{2} \mathrm{O}_{2}$ or NO-responding proteins could not be addressed, until the development of DiaAlk. 
Using DiaAlk labeling coupled to shotgun MS, Akter and Fu et al. identified a total of 387 Ssulfinylated sites in 296 proteins common to the two cell lines analyzed. They also found that $40 \%$ of the $S$-sulfinylated sites are also present in the $S$-sulfenylome, consistent with the lineage of these modifications. Interestingly, the $S$-sulfenylome is much more responsive to exogenous $\mathrm{H}_{2} \mathrm{O}_{2}$ compared to the $S$-sulfinylome, consistent with the more facile attack of $\mathrm{H}_{2} \mathrm{O}_{2}$ on a thiol than on R-SOH. Lastly, by comparing the turnover of $\mathrm{R}-\mathrm{SO}_{2} \mathrm{H}$ sites between wild type mouse fibroblasts and those lacking $\mathrm{Srx}$, they identified 55 new potential substrates of Srx.

These data provide a robust tool to explore a new realm of redox biology, the sulfinylation of cysteine residues at the individual protein and proteome-wide levels. DiaAlk will be invaluable to decipher the role of cysteine sulfinic acid formation as a regulatory switch or as an irreversibly oxidized end product. The low responsiveness of $S$-sulfinylation to $\mathrm{H}_{2} \mathrm{O}_{2}$ suggests that these events accumulate during proteins' lifetime, and thus should serve as good markers of chronic oxidative stress. Reduction of $S$-sulfinylated cysteine residues by sulfiredoxin could be a repair mechanism, or alternatively, indicate the presence of a regulatory switch. $S$-sulfinylation is probably non-enzymatic, requiring relatively high levels of $\mathrm{H}_{2} \mathrm{O}_{2}$, other peroxides, or other electrophiles. Its occurrence as a regulatory switch might thus be seen under oxidative stress, or within subcellular compartments accumulating $\mathrm{H}_{2} \mathrm{O}_{2}$ as is the case for one of the newly identified Srx substrates, the protein tyrosine phosphatase PTPN12. To elucidate the role of the sulfinic acid switches of other new sulfiredoxin substrates such as Parkinson disease protein DJ-1 and actin regulator cofilin, we will have to consider that oxidative stress is part of normal physiology. The newly identified Srx substrates also raise exciting questions about the slow kinetics and specificity of Srx catalysis. ${ }^{12}$

Figure 1. Milestone discoveries in redox biology. The progression of available tools and approaches has facilitated the expansion of known modifications and functions of cysteine residues.

\section{References}

1. Yang, K.S. et al. Inactivation of human peroxiredoxin I during catalysis as the result of the oxidation of the catalytic site cysteine to cysteine-sulfinic acid. J Biol Chem 277, 38029-36 (2002).

2. $\quad$ Biteau, B., Labarre, J. \& Toledano, M.B. ATP-dependent reduction of cysteine-sulphinic acid by S. cerevisiae sulphiredoxin. Nature 425, 980-4 (2003).

3. Akter, S. et al. Chemical proteomics reveals new targets of cysteine sulfinic acid reductase. Nat Chem Biol (2018).

4. Laurent, T.C., Moore, E.C. \& Reichard, P. Enzymatic Synthesis of Deoxyribonucleotides. Iv. Isolation and Characterization of Thioredoxin, the Hydrogen Donor from Escherichia Coli B. $J$ Biol Chem 239, 3436-44 (1964).

5. Zheng, M., Aslund, F. \& Storz, G. Activation of the OxyR transcription factor by reversible disulfide bond formation. Science 279, 1718-21 (1998).

6. Stamler, J.S. et al. S-nitrosylation of proteins with nitric oxide: synthesis and characterization of biologically active compounds. Proc Natl Acad Sci U S A 89, 444-8 (1992).

7. $\quad$ Sundaresan, M., Yu, Z.X., Ferrans, V.J., Irani, K. \& Finkel, T. Requirement for generation of H2O2 for platelet-derived growth factor signal transduction. Science 270, 296-9 (1995).

8. D'Autreaux, B. \& Toledano, M.B. ROS as signalling molecules: mechanisms that generate specificity in ROS homeostasis. Nat Rev Mol Cell Biol 8, 813-24 (2007).

9. Wood, Z.A., Poole, L.B. \& Karplus, P.A. Peroxiredoxin evolution and the regulation of hydrogen peroxide signaling. Science 300, 650-3 (2003).

10. Jeong, W., Bae, S.H., Toledano, M.B. \& Rhee, S.G. Role of sulfiredoxin as a regulator of peroxiredoxin function and regulation of its expression. Free Radic Biol Med 53, 447-56 (2012).

11. Hanzen, S. et al. Lifespan Control by Redox-Dependent Recruitment of Chaperones to Misfolded Proteins. Cell 166, 140-51 (2016).

12. Roussel, X. et al. Evidence for the formation of a covalent thiosulfinate intermediate with peroxiredoxin in the catalytic mechanism of sulfiredoxin. J Biol Chem 283, 22371-82 (2008).

\section{COMPETING FINANCIAL INTEREST:}

There is NO competing interest. 
Redox biochemistry
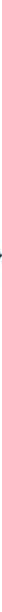